\title{
Metal contamination of agricultural soils in the copper mining areas of Singhbhum shear zone in India
}

\author{
Soma Giri ${ }^{1, *}$, Abhay Kumar Singh ${ }^{1}$ and Mukesh Kumar Mahato ${ }^{2}$ \\ ${ }^{1}$ Natural Resources and Environmental Management Group, CSIR-Central Institute of Mining and Fuel Research, \\ Barwa Road, Dhanbad 826 015, India. \\ ${ }^{2}$ Department of Chemistry, Vinoba Bhave University, Hazaribag 825 301, India. \\ *Corresponding author.e-mail: soma0307@gmail.com
}

MS received 8 November 2016; revised 13 January 2017; accepted 22 January 2017; published online 7 June 2017

The study was intended to investigate the heavy metal contamination in the agricultural soils of the copper mining areas in Singhbhum shear zone, India. The total concentrations of the metals were determined by inductively coupled plasma-mass spectrometer (ICPMS). Pollution levels were assessed by calculating enrichment factor $(\mathrm{EF})$, geo-accumulation index $\left(I_{\text {geo }}\right)$, contamination factors $(\mathrm{CF})$, pollution load index $(P L I)$, Nemerow index and ecological risk index $\left(R_{I}\right)$. The metal concentrations in the soil samples exceeded the average shale values for almost all the metals. Principal component analysis resulted in extraction of three factors explaining $82.6 \%$ of the data variability and indicated anthropogenic contribution of $\mathrm{Cu}, \mathrm{Ni}, \mathrm{Co}, \mathrm{Cr}, \mathrm{Mn}$ and $\mathrm{Pb}$. The $\mathrm{EF}$ and $I_{\text {geo }}$ values indicated very high contamination with respect to $\mathrm{Cu}$ followed by $\mathrm{As}$ and $\mathrm{Zn}$ in the agricultural soils. The values of $P L I, R_{I}$ and Nemerow index, which considered the overall effect of all the studied metals on the soils, revealed that $50 \%$ of the locations were highly polluted with respect to metals. The pollution levels varied with the proximity to the copper mining and processing units. Consequently, the results advocate the necessity of periodic monitoring of the agricultural soils of the area and development of proper management strategies to reduce the metal pollution.

Keywords. Agricultural soil; heavy metals; copper mining areas; multivariate analysis; geo-accumulation index; Nemerow index.

\section{Introduction}

The contamination of agricultural soils by heavy metals has aroused considerable apprehension worldwide due to their toxicity and persistence (Cao et al. 2010; Ma et al. 2015). The sources of heavy metals in the soil can be of both natural and anthropogenic origins. Of the other anthropogenic sources, mining has emerged as one of the most important sources of heavy metals in the surrounding environment. Mining and milling operation together with grinding, concentrating ores and disposal of tailings, along with mine and mill waste water, provide obvious sources of contamination (Adriano 2001; Li et al. 2014). Heavy metal contamination of the soils in the vicinity of the mine sites are recognized as one of the serious environmental problems around the world. The heavy metal contaminated soils have a potential to contaminate the other constituents of the environment like surface and groundwater sources, air and the agricultural crops growing on them (Borgese et al. 2013; Ji et al. 2013; Li et al. 2014). 
Some metals like $\mathrm{Cu}, \mathrm{Fe}, \mathrm{Mn}, \mathrm{Ni}$ and $\mathrm{Zn}$ are important as micronutrients for life processes in living organisms for life and regulate many physiological function of the body. However, many other metals like $\mathrm{As}, \mathrm{Cd}, \mathrm{Cr}$ and $\mathrm{Pb}$ have no known physiological activity and may exhibit toxicity even at low concentrations (Bruins et al. 2000; Cohen et al. 2001). Long-term exposure to heavy metals may lead to many adverse health effects including a variety of cancers, mental retardation and neurological, cardiovascular, kidney and bone diseases (Adriano 2001; Prüss-Ustün et al. 2011).

The study area falls in the Singhbhum shear zone (SSZ) which is known for its rich mineral deposits and production of copper and uranium ores. Although, few studies were carried out on the heavy metal distribution in the sediments, surface and groundwater sources and fish samples of the Subarnarekha River basin of which the study area is a part (Upadhyay et al. 2006; Giri et al. 2013; Giri and Singh 2014a, b, 2015, 2016). The studies indicated the deleterious effects of the copper mining and milling activities on the environmental components.

However, practically no serious efforts has been made to study the heavy metal contents of agricultural soils in the vicinity of copper mining areas of Singhbhum shear zone. The present study aims (1) to determine the concentration of the heavy metals (As, Cd, Co, Cr, Cu, Fe, Mn, Ni, Pb, Se, $\mathrm{V}$ and $\mathrm{Zn}$ ) in the agricultural soils, (2) to ascertain whether there was contamination with respect to these metals using various indices, and (3) to identify the sources of the metals in the soils by multivariate statistical analysis.

\section{Materials and methods}

\subsection{Site description}

The study was carried out in the copper mining areas of Singhbhum Shear Zone of Jharkhand which is known to be rich in mineral resources like copper, iron, uranium, gold and kyanite. The present study area extends from $86^{\circ} 20^{\prime}$ to $86^{\circ} 30^{\prime} \mathrm{E}$ longitudes and $22^{\circ} 30^{\prime}$ to $22^{\circ} 42^{\prime} \mathrm{N}$ latitudes, covering an area of about $160 \mathrm{~km}^{2}$ and falls in Mosabani, Dhalbhumgarh and Ghatsila blocks of East Singhbhum district of Jharkhand state. The climate of the study area is temperate. Annual rainfall is 1200-1400 mm. This area is subject to the southwest monsoon and receives heavy rain (about 80\%) during June to September (monsoon season). The major crops grown in the study area are paddy, maize, pulses and some seasonal vegetables and fruits.

The Singhbhum shear zone forms an arcuate highly deformed linear zone in the Singhbhum crustal province and is known as one of the most potential sulphide bearing stretch of India. Some of the copper mining and processing entities of the area are at Rakha, Kendadih, Surda, Badia, Mosabani, Ghatsila and Maubhandar. The main copper belt extends over a distance of $130 \mathrm{~km}$ and harbors $18 \%$ of the total copper reserves of India. The copper mineralization along Singhbhum copper belt is located along the Dhanjori group of rocks at south of shear zone and Singhbhum group of rocks at north of shear zone. The copper sulphide mineralization is associated mainly with the metavolcanics and meta-tuff sequences of the Dhanjori and Singhbhum Groups. The sulphide minerals consist predominantly of chalcopyrite, followed by pyrite and pyrrhotite, accompanied by magnetite and minor pentlandite, millerite, violarite, sphalerite and molybdenite. The gangue minerals are quartz, biotite, chlorite and sericite in variable proportions. The major rock types of the region are soda granite, Dhanjori lavas and Epidiorite-schist (Dunn and Dey 1942; Mukherjee 1968).

\subsection{Sampling and analysis}

Random samples were collected from 16 locations in the vicinity of the mining affected areas. The sampling locations were between 0.5 and $2.5 \mathrm{~km}$ from the mining or processing industries. Some locations (sample nos. 2, 3 and 6) were selected to study the effect of vehicular and other anthropogenic activities. The sample no. 1 served as a control as it was located in the forest area far from any copper mining and processing activities. The samples were representative for the study area.

Each soil sample of about $1 \mathrm{~kg}$ was taken from the depths of $0-15 \mathrm{~cm}$, which represented the plough layer. Then, the soil samples were packed and sealed in polyethylene bags and transported to the laboratory for sample preparation. The samples were air dried at room temperature $\left(25-30^{\circ} \mathrm{C}\right)$. Representative sub-sampling of the dried soils was carried out by coning and quartering method for uniform mixing and reducing variability of the samples and reducing to a desired weight (Rubio and Ure 1993; Loska et al. 2004; Alloway 2013). Then about $100 \mathrm{~g}$ of the sample was taken in a porcelain dish and dried in an oven at $110^{\circ} \mathrm{C}$ for $24 \mathrm{hr}$. The 
samples were powdered in a dry mortar-pestle and sieved through standard sieve of 200 mesh size (Giri et al. 2013). The samples were then subjected to digestion in microwave by the method 3052 as given by USEPA (1996). Aliquots were preserved for the analysis of metals. Concentrations of As, Cd, Co, $\mathrm{Cr}, \mathrm{Cu}, \mathrm{Fe}, \mathrm{Mn}, \mathrm{Ni}, \mathrm{Pb}, \mathrm{V}$ and $\mathrm{Zn}$ were determined in soil samples using inductively coupled plasmamass spectrometry (ICP-MS, Perkin Elmer Elan DRC-e).

\subsection{Quality assurance and quality control}

For the validation of the analytical procedure, standard reference materials (SRM) of estuarine sediment (SRM 1646a) supplied by the National Institute of Standards and Technology (NIST), USA was used. The heavy metal concentrations analyzed in the SRMs were in good agreement with the certificate values, which confirmed the feasibility of the analytical protocols in the determination of heavy metals in soil. The percentage of recovery varied from 89.4 to 109.7.

\subsection{Statistical analysis}

Pearson's correlation is a bivariate correlation which gives some idea regarding the relationship between two sets of data, and its coefficient is a measure of the strength of the association between the two variables (Ma et al. 2015). For the present study, Pearson's correlation analysis was selected to determine the relationships among different heavy metals. Principal component analysis (PCA) is a variation reduction technique in which a number of measured parameters can be transformed into a small number of artificial variables known as principal components (PC). The number of extracted $\mathrm{PC}$ is equal to the number of variables included in the analysis; however, normally PCs having eigen values $>1$ are taken into consideration as they explain for the maximum variance in the observed parameter (Kolsi et al. 2013; Huang et al. 2014). Varimax rotation is applied to all the extracted principal components to reduce the contribution of the variables which are not significant (Closs and Nichol 1975). Each variable considered for PCA has a weight factor associated with it. This weight factor, also referred to as PC score, is the correlation between the original variable and a factor. A PC score close to \pm 1 indicates a strong correlation between the given variable and the factor. To evaluate the validity of PCA, the Barlett's test of sphericity and Kaiser-Meyer-Olkin (KMO) test as a measure of sampling adequacy were taken into consideration. Large KMO value $(>0.5)$ and suitable significance of Barlett's test $(p<0.05)$ were necessary to ensure the validity of PCA (Chen et al. 2014; Fu et al. 2014; Ma et al. 2015).

\subsection{Calculation of indices to assess anthropogenic influence}

\subsubsection{Enrichment factor (EF)}

In order to assess the degree of anthropogenic influence with respect to metals, the enrichment factor (EF) was calculated for each metal in the soil using the equation (1):

$$
\mathrm{EF}=\frac{\left(C_{\mathrm{X}} / C_{\mathrm{Fe}}\right)_{\mathrm{s}}}{\left(C_{\mathrm{X}} / C_{\mathrm{Fe}}\right)_{\mathrm{c}}}
$$

where $C_{\mathrm{X}}$ and $C_{\mathrm{Fe}}$ refer to the concentration of element $\mathrm{X}$ and $\mathrm{Fe}$ in the soil (s) and earth's crust (c), respectively. Iron was used as reference element (Schiff and Weisberg 1999; Turner and Millward 2000) and the metal concentrations were normalized to the textural characteristic of soils with respect to $\mathrm{Fe}$. A five-category ranking system is used in this paper to denote the degree of anthropogenic contamination (Sutherland 2000; Kartal et al. 2006; Giri et al. 2013). The categories are:

- EF $<2$ states deficiency to minimal contamination

- $\mathrm{EF}=2-5$ moderate contamination

- $\mathrm{EF}=5-20$ significant contamination

- $\mathrm{EF}=20-40$ very high contamination

- $\mathrm{EF}>40$ extremely high contamination.

\subsubsection{Geo-accumulation index $\left(I_{\text {geo }}\right)$}

Pollution levels of metal in soils can also be exemplified by the calculations of the geo-accumulation index values put forward by Muller (1979), which can be evaluated by equation (2). This is a way to assess the pollution levels in soils or sediments with respect to the toxic metals by comparing the present and past concentrations.

$$
I_{\text {geo }}=\log _{2}\left(C_{n} / 1.5 B_{n}\right)
$$

where $C_{n}$ is the measured concentration of the heavy metal $n$ in the soil and $B_{n}$ is the geochemical background reference value. The reference value used for the study was average shale and control soil. The constant 1.5 is introduced in the equation 
arbitrarily to account for the natural fluctuations that may have occurred throughout the years in the environment (Christophoridis et al. 2009).

\subsubsection{Pollution load index (PLI)}

Pollution load index (PLI) was introduced by Tomlison et al. (1980) to determine the extent of pollution due to the combined effect of metals in the soils (Giri et al. 2013). PLI is calculated as geometric mean of concentration factor $(\mathrm{CF})$ value of $n$ number of studied metals (equation 3 ). The index is based on the CF of each metal present in the soil or sediment which is expressed as equation (4) (Salomons and Forstner 1984).

$$
\mathrm{PLI}=\left(\mathrm{CF}_{1} \times \mathrm{CF}_{2} \times \mathrm{CF}_{3} \times \cdots \times \mathrm{CF}_{n}\right)^{1 / n}
$$

where $n$ is the number of metals and CF is the contamination factor.

$$
\mathbf{C F}=\frac{\text { Metal concentration in soil }}{\text { Metal concentration in average shale }} \text {. }
$$

Pollution load index $(P L I)$ is a comparative means to evaluate the level of metal pollution and classified as follows:

- No pollution $(P L I<1)$

- Moderate pollution $(1<P L I<2)$

- Heavy pollution $(2<P L I<3)$

- Extremely heavy pollution $(3<P L I)$.

\subsubsection{Nemerow comprehensive index}

For assessing the environmental quality of the agricultural soils around the copper mining areas, another index, i.e., the Nemerow comprehensive index $\left(P_{s}\right)$ (Li et al. 2008) was used. The index is calculated using the following equations (5-7):

$$
\begin{aligned}
C_{f}^{i} & =\frac{C_{s}^{i}}{C_{n}^{i}} \\
m C_{d} & =\left(\sum_{i=1}^{n} C_{f}^{i}\right) / n . \\
P_{s} & =\sqrt{\frac{\left(m C_{d}\right)^{2}+\left(C_{f \max }^{i}\right)^{2}}{2}},
\end{aligned}
$$

where $C_{s}^{i}$ is the measured concentration of metal $i$ in the soil sample (unit: $\mathrm{mg} / \mathrm{kg}$ ), $C_{n}^{i}$ is the geochemical background value (average shale in this study) of metal $i$, (unit: $\mathrm{mg} / \mathrm{kg}$ ), $C_{f}^{i}$ is the single pollution index of metal $i, C_{f_{\max }}^{i}$ is the maximum value of single pollution index of all metals, $n$ is the number of metals measured in the soil sample (i.e., $n=11$ in this study), $m C_{d}$ is Hakanson's modified degree of contamination index which summates all the single pollution indices $\left(C_{f}^{i}\right)$ to estimate the overall contamination of metals at a location (Hakanson 1980).

The $m C_{d}$ value is classified into seven classes by Brady et al. (2015) as:

- $m C_{d}<1.5$ as unpolluted;

- $1.5 \leq m C_{d}<2$ as slightly polluted;

- $2 \leq m C_{d}<4$ as moderately polluted;

- $4 \leq m C_{d}<8$ as considerably polluted;

- $8 \leq m C_{d}<16$ as highly polluted;

- $16 \leq m C_{d}<32$ as strongly polluted;

- $m C_{d} \geq 32$ as extremely polluted.

The Nemerow index is classified into five groups by $\mathrm{Wu}$ et al. (2015) as:

- uncontaminated if $P_{s}<1$;

- slightly contaminated if $1 \leq P_{s}<2$;

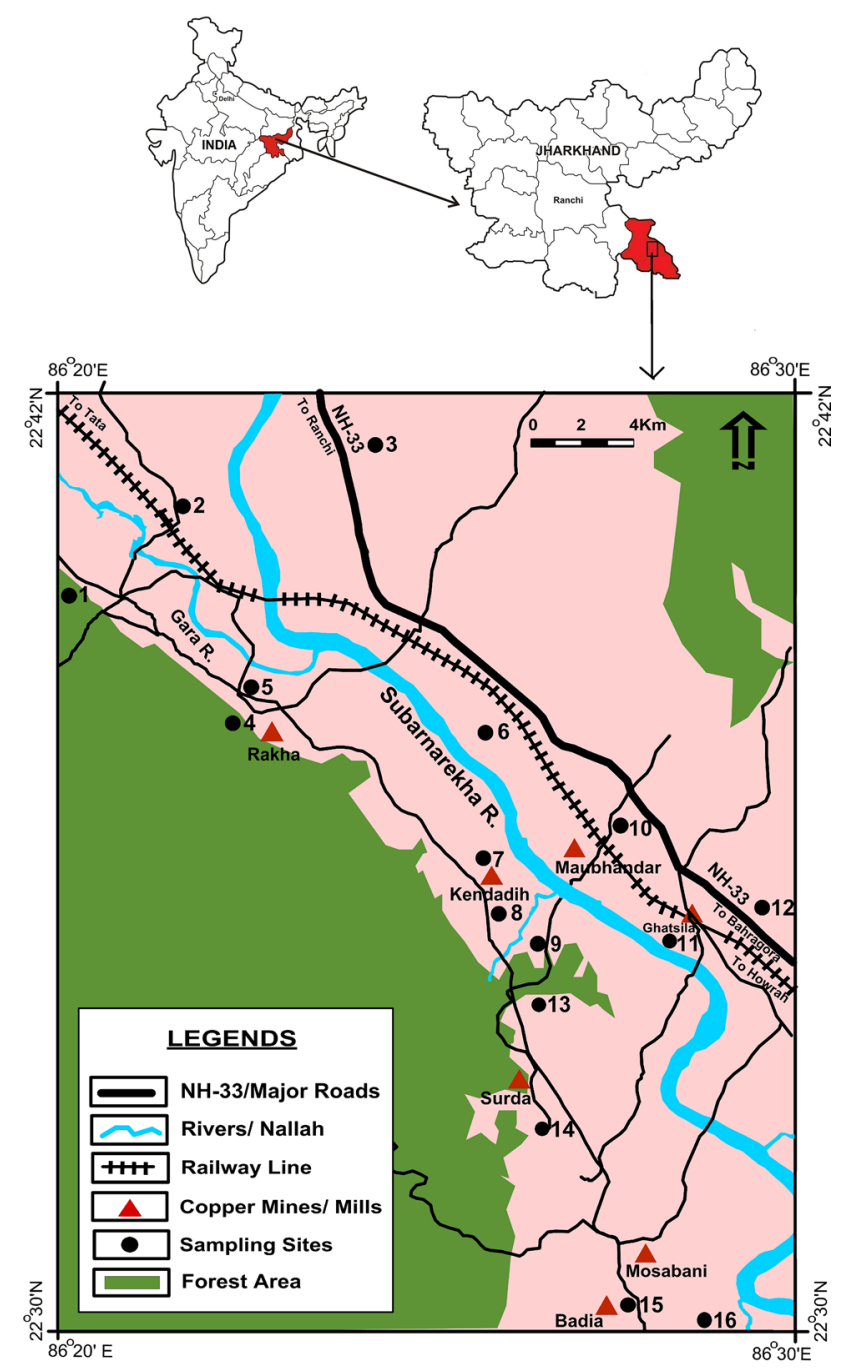

Figure 1. Map of the study area with sampling locations. 
- moderately contaminated if $2 \leq P_{s}<3$;

- strongly contaminated if $3 \leq P_{s}<5$; and

- seriously contaminated if $P_{s} \geq 5$ (Ma et al. 2015).

\section{Assessment of potential ecological risk}

Potential ecological risk assessment was proposed by Hakanson (1980) to assess the degree of heavy metal pollution in soil or sediments, according to the toxicity of heavy metals and the response of the environment. Risk index $\left(R_{I}\right)$ is introduced to evaluate the contamination degree of the soils considering the effect of multiple metals. $R_{I}$ is defined according to equation (8) as summation of $E_{r}^{i}$ of heavy metals where $E_{r}^{i}$ is the monomial potential ecological risk factor defined by equation (9).

$$
\begin{aligned}
R_{I} & =\sum E_{r}^{i} \\
E_{r}^{i} & =T_{i} \frac{C_{i}}{\mathrm{C}_{0}}
\end{aligned}
$$

$T_{i}$ is the toxic response factor for the metals and the values for $\mathrm{As}, \mathrm{Cd}, \mathrm{Cu}, \mathrm{Pb}, \mathrm{Ni}, \mathrm{Zn}$ and $\mathrm{Cr}$ are
10, 30, 5, 5, 5, 1 and 2, respectively (Hilton et al. 1985; Wang et al. 2011). $C_{i}$ is the concentration of metals in the soil, and $C_{0}$ is a reference value for metals. In the present study, the concentrations of the metals of the control site are taken as reference values.

The degree of $E_{r}^{i}$ is classified as follows: $E_{r}^{i}<40$, low risk; $40 \leq E_{r}^{i}<80$, moderate risk; $80 \leq E_{r}^{i}<$ 160 , considerable risk; $160 \leq E_{r}^{i}<320$, high risk; and $E_{r}^{i} \geq 320$, very high risk. The potential ecological $R_{I}$ can be grouped into four categories with slight modification according to the recommended values by $\mathrm{Wu}$ et al. (2015): $R_{I}<100$, low risk; $100 \leq R_{I}<200$, moderate risk; $200 \leq R_{I}<400$, considerable risk; and $R_{I} \geq 400$, very high risk.

\section{Results and discussion}

\subsection{Distribution of metals in soil}

Large variations were observed in the concentration of the metals collected from the 16 locations around the copper mining areas of SSZ (figure 1).

Table 1. Descriptive data of metals $\left(\mathrm{mg} \mathrm{kg}^{-1}\right)$ in agricultural soils from the copper mining areas of Singhbhum shear zone.

\begin{tabular}{lrlrrrrrrrrr}
\hline & $\mathrm{As}$ & $\mathrm{Cd}$ & $\mathrm{Co}$ & $\mathrm{Cr}$ & $\mathrm{Cu}$ & $\mathrm{Fe}$ & $\mathrm{Mn}$ & $\mathrm{Ni}$ & $\mathrm{Pb}$ & $\mathrm{V}$ & $\mathrm{Zn}$ \\
\hline Minimum & 9.6 & 0.08 & 12.1 & 65.2 & 54.3 & 20,147 & 111.7 & 35.2 & 21.3 & 65.3 & 52.9 \\
Maximum & 121.1 & 0.84 & 63.8 & 751.0 & 3314.4 & 64,695 & 1045.0 & 303.4 & 102.6 & 200.8 & 621.4 \\
Geomean & 29.7 & 0.34 & 32.3 & 149.6 & 218.0 & 38,215 & 520.8 & 94.2 & 47.0 & 113.6 & 210.6 \\
World average $^{\mathrm{a}}$ & 6.0 & 0.350 & 8.0 & 70.0 & 30.0 & 40,000 & 1000 & 50.0 & 35.0 & 90.0 & 90.0 \\
Shale average $^{\mathrm{b}}$ & 13.0 & 0.3 & 19.0 & 90.0 & 45.0 & 47,200 & 850 & 68.0 & 20.0 & 130.0 & 95.0 \\
\hline
\end{tabular}

${ }^{\mathrm{a}}$ Bowen (1979), ${ }^{\mathrm{b}}$ Turekian and Wedepohl (1961).

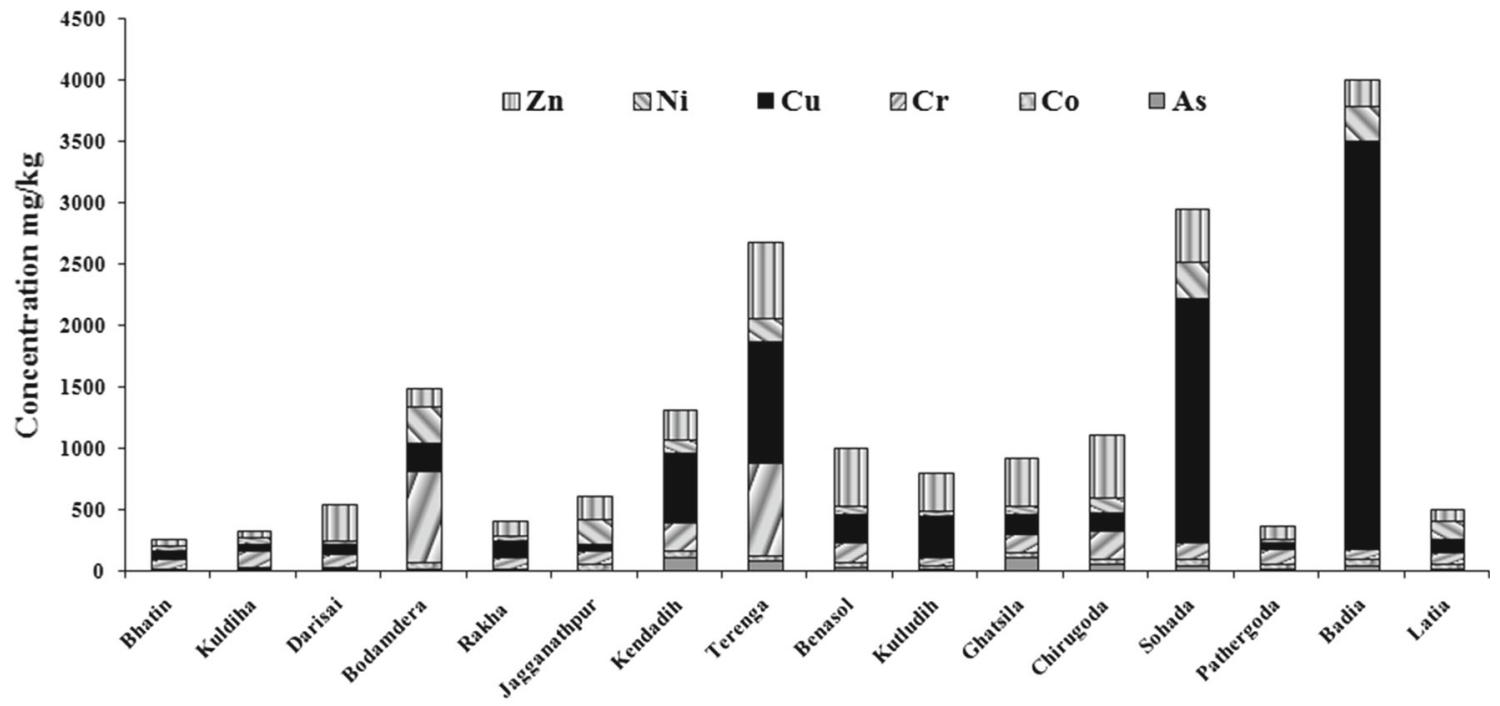

Locations

Figure 2. Concentrations of $\mathrm{Zn}, \mathrm{Ni}, \mathrm{Cu}, \mathrm{Cr}$, Co and $\mathrm{As}\left(\mathrm{mg} \mathrm{kg}^{-1}\right)$ in the agricultural soils of the study area. 


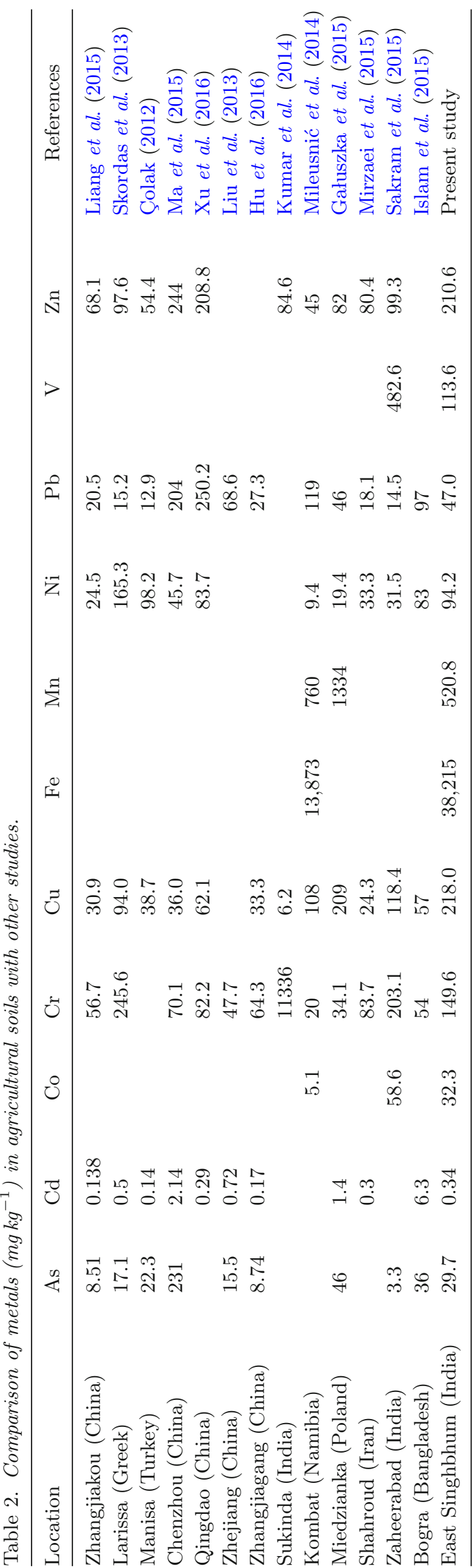

The minimum, maximum and geometric mean concentrations of the metals in the study area are provided in table 1 . As frequently observed in the environmental samples, the concentrations of metals in the soil were better elucidated by the log normal distribution and thus, the central tendency was represented by geometric mean. The geometric mean concentration of $\mathrm{As}, \mathrm{Cd}, \mathrm{Co}, \mathrm{Cr}, \mathrm{Cu}, \mathrm{Fe}, \mathrm{Mn}$, $\mathrm{Ni}, \mathrm{Pb}, \mathrm{V}$ and $\mathrm{Zn}$ was 29.7, 0.34, 32.3, 149.6, 218, $38215,520.8,94.2,47,113.6$ and $210.6 \mathrm{mg} \mathrm{kg}^{-1}$, respectively. The sequence of the metal concentration was generally as $\mathrm{Fe}>\mathrm{Mn}>\mathrm{Cu}>\mathrm{Zn}>\mathrm{Cr}>$ $\mathrm{V}>\mathrm{Ni}>\mathrm{As}>\mathrm{Pb}>\mathrm{Co}>\mathrm{Cd}$. The metal concentrations in the soil of the study area exceeded the values of the average concentration of metals in the shale (Turekian and Wedepohl 1961) and world average (Bowen 1979) for almost all the metals. As the study area is characterized by the presence of metal bearing formations accompanied with mining and industrial operations, it is obvious to have elevated levels of metals in the soils (Forstner and Wiltman 1983; Preston and Chester 1996). However, the amplification was more prominent for As, $\mathrm{Co}, \mathrm{Cr}, \mathrm{Cu}, \mathrm{Ni}$ and $\mathrm{Zn}$. The concentrations of these metals in the soils are given in figure 2. The concentrations of metals were observed to be generally higher at the locations which were near to existing or abandoned copper mining and processing units, e.g., Badia, Sohada, Terenga, Kendadih and Bodamdera.

Table 2 provides comparison of the metals in the agricultural soils of the study area with the other agricultural soils worldwide. The concentrations of the metals are in accordance with the other studies except for $\mathrm{Cu}$ which may be attributed to the copper mineralization and mining in the study area.

\subsection{Statistical analysis}

Pearson's correlation coefficients of the metals in the agricultural soils from the study area are depicted in table 3 . Significant positive associations were seen $(p<0.01)$ for Fe with $\mathrm{Mn}$, As and $\mathrm{V}$; V with $\mathrm{As}$ and $\mathrm{Cd}$; $\mathrm{Cd}$ with $\mathrm{Zn}$; $\mathrm{Cu}$ with $\mathrm{Ni}$ and $\mathrm{Co}$; $\mathrm{Zn}$ with $\mathrm{Pb} ; \mathrm{Pb}$ with $\mathrm{Mn}$. A strong positive correlation necessarily do not point towards an identical source (Hani and Pazira 2011), however, inter-elemental relationships can provide remarkable suggestions on the pathways and even sources of the metals (Chen et al. 2014), for example, positive correlations between $\mathrm{Cu}$ and $\mathrm{Ni}$ and $\mathrm{Cu}$ and $\mathrm{Co}$ indicated a possibility of a common source which 
Table 3. Pearson correlation matrix between different metals in the soils of copper mining areas of Singhbhum shear zone $(n=16)$.

\begin{tabular}{|c|c|c|c|c|c|c|c|c|c|c|c|}
\hline & Mn & $\mathrm{Cu}$ & $\mathrm{Pb}$ & $\mathrm{Zn}$ & $\mathrm{Ni}$ & $\mathrm{Co}$ & As & $\mathrm{Cd}$ & $\mathrm{Cr}$ & $\mathrm{V}$ & $\mathrm{Fe}$ \\
\hline Mn & 1.000 & 0.019 & $0.706^{*}$ & $0.584^{*}$ & 0.244 & 0.332 & $0.591^{*}$ & $0.482^{*}$ & $0.454^{*}$ & $0.688^{*}$ & $0.754^{*}$ \\
\hline $\mathrm{Cu}$ & & 1.000 & -0.006 & 0.222 & $0.667^{*}$ & $0.511^{*}$ & 0.234 & $0.387^{* *}$ & 0.004 & 0.263 & 0.234 \\
\hline $\mathrm{Pb}$ & & & 1.000 & $0.844^{*}$ & 0.199 & 0.255 & $0.461^{*}$ & $0.697^{*}$ & $0.665^{*}$ & $0.741^{*}$ & $0.685^{*}$ \\
\hline $\mathrm{Zn}$ & & & & 1.000 & 0.209 & 0.166 & $0.561^{*}$ & $0.856^{*}$ & $0.356^{* *}$ & $0.732^{*}$ & $0.629 *$ \\
\hline $\mathrm{Ni}$ & & & & & 1.000 & $0.832^{*}$ & 0.108 & 0.237 & $0.446^{*}$ & 0.257 & 0.275 \\
\hline $\mathrm{Co}$ & & & & & & 1.000 & 0.251 & 0.195 & $0.429^{* *}$ & $0.369^{* *}$ & $0.421^{* *}$ \\
\hline As & & & & & & & 1.000 & 0.580 & 0.270 & $0.771^{*}$ & $0.770^{*}$ \\
\hline $\mathrm{Cd}$ & & & & & & & & 1.000 & 0.200 & $0.808^{*}$ & $0.696^{*}$ \\
\hline $\mathrm{Cr}$ & & & & & & & & & 1.000 & $0.398^{* *}$ & $0.458^{*}$ \\
\hline $\mathrm{V}$ & & & & & & & & & & 1.000 & $0.932^{*}$ \\
\hline $\mathrm{Fe}$ & & & & & & & & & & & 1.000 \\
\hline
\end{tabular}

* Correlation significant at the 0.01 level (two tailed).

** Correlation significant at the 0.05 level (two tailed).

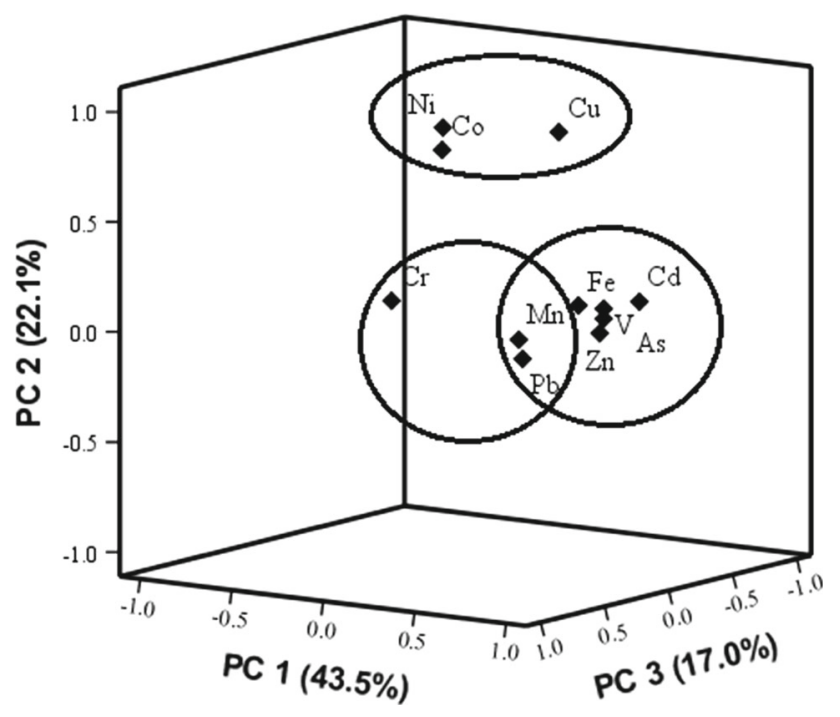

Figure 3. Loading plots of principal component analysis for the three rotated components.

may be derived from mining and processing of copper ores. Principal component analysis (PCA) was carried out on the heavy metal data of the agricultural soil samples in order to get a better view of their interrelationships and to reduce the dimensionality of the dataset, since a few of the new components explain the major part of data variance. It also helps in assigning source identity to each one of the PCs (Miller and Miller 2000). The KMO (0.615) and Barlett's test $(p<0.001)$ validated the approach of PCA. In the present set of data, three principal components were extracted explaining $82.6 \%$ of total variance (figure 3 ). The loading factors indicate that the first principal component (PC1) was associated with As, Cd, Fe, $\mathrm{Mn}, \mathrm{Pb}, \mathrm{V}$ and $\mathrm{Zn}$ explaining $43.5 \%$ of variance and seemed to be related to earth's crust and geological formation of the area. The second component elucidated $22.1 \%$ of variation in the data and is underlined by significant factor loading for $\mathrm{Cu}, \mathrm{Ni}$ and Co. This factor can be associated to the extensive copper mining in the study area. $\mathrm{Ni}$ and $\mathrm{Co}$ are exposed during copper mining and smelting as they are associated with copper deposits. The study area is rich in copper mineralization, so it is obvious to have high concentration of the $\mathrm{Cu}$ along with $\mathrm{Ni}$ and $\mathrm{Co}$. But the concentrations of these metals are even higher than the background rock formations thus pointing towards the effect of mining and allied activities of the study area. The concentration of $\mathrm{Cu}, \mathrm{Ni}$ and $\mathrm{Co}$ in the background rocks have been reported to be 46-52, 65-78 and 22-30 $\mathrm{mg} \mathrm{kg}^{-1}$, respectively (Mukherjee 1968).

The third factor having high loadings for $\mathrm{Cr}$, $\mathrm{Mn}$ and $\mathrm{Pb}$ explicated $17.0 \%$ of the variance. This factor appeared to have arisen from other anthropogenic activities like waste incineration, coal combustion and vehicular pollution.

\subsection{Contamination and toxicity assessment of metals in soil}

Enrichment factor analysis indicated moderate to extremely high contamination of metals in the agricultural soils of the study area (table 4). The EF ranged from 1.4 to 8.9 for As, 0.59 to 2.48 for $\mathrm{Cd}$, 1.01 to 5.62 for Co, 0.97 to 8.58 for Cr, 1.7 to 80.7 for $\mathrm{Cu}, 0.29$ to 1.58 for $\mathrm{Mn}, 0.78$ to 7.05 for Ni, 1.54 to 4.42 for $\mathrm{Pb}, 0.87$ to 1.56 for $\mathrm{V}$ and 0.68 to 5.64 for $\mathrm{Zn}$. Of all the studied metals, enrichment factor indicated highest contamination with respect to $\mathrm{Cu}$ which depicted significant contamination to extremely high contamination in half of the 
Table 4. Enrichment factor of metals in soil with respect to different locations of the copper mining areas of Singhbhum shear zone.

\begin{tabular}{clccccccccccc}
\hline Code & Location & $\mathrm{As}$ & $\mathrm{Cd}$ & $\mathrm{Co}$ & $\mathrm{Cr}$ & $\mathrm{Cu}$ & $\mathrm{Fe}$ & $\mathrm{Mn}$ & $\mathrm{Ni}$ & $\mathrm{Pb}$ & $\mathrm{V}$ & $\mathrm{Zn}$ \\
\hline 1 & Bhatin & 2.35 & 0.62 & 1.59 & 1.84 & 3.53 & 1.00 & 0.29 & 1.16 & 2.68 & 1.56 & 1.33 \\
2 & Kuldiha & 1.85 & 0.59 & 1.32 & 1.73 & 1.70 & 1.00 & 1.17 & 0.82 & 2.64 & 0.87 & 0.68 \\
3 & Darisai & 2.76 & 2.18 & 1.01 & 1.78 & 2.95 & 1.00 & 0.86 & 0.85 & 3.60 & 1.08 & 4.83 \\
4 & Bodamdera & 1.43 & 0.64 & 3.49 & 8.58 & 5.35 & 1.00 & 0.94 & 4.49 & 3.56 & 0.97 & 1.58 \\
5 & Rakha & 1.61 & 1.94 & 1.20 & 1.84 & 5.46 & 1.00 & 0.75 & 1.15 & 1.98 & 0.93 & 2.43 \\
6 & Jagganathpur & 1.72 & 1.66 & 5.62 & 2.89 & 2.98 & 1.00 & 1.58 & 7.05 & 4.15 & 1.34 & 4.79 \\
7 & Kendadih & 7.01 & 0.96 & 1.77 & 1.94 & 9.52 & 1.00 & 0.70 & 1.16 & 1.54 & 0.99 & 1.97 \\
8 & Terenga & 5.96 & 2.13 & 1.80 & 7.20 & 19.07 & 1.00 & 0.81 & 2.39 & 4.42 & 1.10 & 5.64 \\
9 & Benasol & 2.84 & 2.48 & 1.76 & 1.89 & 5.20 & 1.00 & 0.70 & 1.15 & 4.15 & 1.27 & 5.08 \\
10 & Kutludih & 1.71 & 1.13 & 2.38 & 1.05 & 11.00 & 1.00 & 0.81 & 0.96 & 3.71 & 0.96 & 4.75 \\
11 & Ghatsila & 8.89 & 1.90 & 1.84 & 1.65 & 3.48 & 1.00 & 1.02 & 1.03 & 3.32 & 1.14 & 4.01 \\
12 & Chirugoda & 3.39 & 2.05 & 1.37 & 1.88 & 2.43 & 1.00 & 0.90 & 1.29 & 3.16 & 1.13 & 4.02 \\
13 & Sohada & 3.79 & 1.75 & 2.89 & 1.63 & 46.98 & 1.00 & 0.91 & 4.75 & 2.72 & 1.03 & 4.82 \\
14 & Pathergoda & 1.71 & 1.02 & 3.32 & 2.06 & 1.81 & 1.00 & 0.78 & 0.78 & 2.96 & 1.03 & 1.72 \\
15 & Badia & 4.31 & 2.35 & 3.31 & 0.97 & 80.72 & 1.00 & 0.56 & 4.58 & 1.94 & 1.17 & 2.57 \\
16 & Latia & 2.03 & 1.43 & 2.63 & 1.36 & 2.90 & 1.00 & 0.30 & 2.61 & 1.96 & 0.90 & 1.34 \\
\hline
\end{tabular}

Table 5. Geo-accumulation index of metals in soil with respect to different locations of the copper mining areas of Singhbhum shear zone.

\begin{tabular}{|c|c|c|c|}
\hline $\begin{array}{l}I_{\text {geo }} \\
\text { value }\end{array}$ & $\begin{array}{l}I_{\text {geo }} \\
\text { class }\end{array}$ & $\begin{array}{l}\text { Soil quality } \\
\text { (Muller 1969) }\end{array}$ & Metals \\
\hline$>5$ & 6 (>64-fold increase) & Extremely polluted & $\mathrm{Cu}$ \\
\hline $4-5$ & 5 & $\begin{array}{l}\text { Highly polluted to very } \\
\text { highly polluted }\end{array}$ & $\mathrm{Cu}$ \\
\hline $3-4$ & 4 (25-fold increase) & Highly polluted & $\mathrm{Cu}$ \\
\hline $2-3$ & 3 & $\begin{array}{l}\text { Moderately polluted to } \\
\text { highly polluted }\end{array}$ & $\mathrm{Cu}, \mathrm{Zn}, \mathrm{As}, \mathrm{Cr}$ \\
\hline $1-2$ & 2 (five-fold increase) & Moderately polluted & $\mathrm{Cu}, \mathrm{Pb}, \mathrm{Zn}, \mathrm{Ni}, \mathrm{Co}, \mathrm{As}$ \\
\hline $0-1$ & $\begin{array}{l}1 \text { (double the } \\
\text { background value) }\end{array}$ & $\begin{array}{l}\text { Unpolluted to } \\
\text { moderately polluted }\end{array}$ & $\begin{array}{l}\mathrm{Cu}, \mathrm{Pb}, \mathrm{Zn}, \mathrm{Ni}, \mathrm{Co}, \mathrm{As}, \\
\mathrm{Cd}, \mathrm{Cr}, \mathrm{V}\end{array}$ \\
\hline$<0$ & 0 & $\begin{array}{l}\text { Background } \\
\text { concentration }\end{array}$ & $\begin{array}{l}\mathrm{Mn}, \mathrm{Cu}, \mathrm{Pb}, \mathrm{Zn}, \mathrm{Ni} \\
\mathrm{Co}, \mathrm{Cd}, \mathrm{Cr}, \mathrm{V}, \mathrm{Fe}\end{array}$ \\
\hline
\end{tabular}

locations. The EF showed no pollution with respect to $\mathrm{Mn}$ and $\mathrm{V}$ in the study area. At most of the locations, $\mathrm{As}, \mathrm{Pb}, \mathrm{Zn}, \mathrm{Co}, \mathrm{Ni}$ and $\mathrm{Cr}$ were found to be at moderate contaminated stage; however, there were few locations where significant contamination were encountered with respect to these metals which can be attributed to mining, industries and other anthropogenic causes.

The geo-accumulation index proposed by Muller (1969) for the quantification of metal accumulation in sediments or soil consisted of seven classes (0-6) indicating various degrees of enrichment above the background values ranging from unpolluted (class 0) to extremely polluted (class 6) soil quality (table 5). Variations in the calculated $I_{\text {geo }}$ values of the agricultural soils in the study area are presented as boxplots in figure 4. Large variations were observed in the $I_{\text {geo }}$ values for the metals in the study area as metals widely varied from class 0 to class 6 indicating large spatial variations; representing the background status for some metals to extremely polluted status for others. Largest variation was observed for $\mathrm{Cu}$ for which the $I_{\text {geo }}$ values ranged from -0.31 to 5.62 ; thus falling under the $I_{\text {geo }}$ class of 0-6, i.e., unpolluted to extremely polluted status. A moderate-to-high pollution (class 3 ) was indicated by the $I_{\text {geo }}$ values for the metals $\mathrm{Zn}$, As and $\mathrm{Cr}$ at some locations. The $I_{\text {geo }}$ values were calculated for the soils using the control soil also, i.e., soil from the location 1 (figure 4). Except for $\mathrm{V}$, the average $I_{\text {geo }}$ values of all the metals were greater than zero when calculated with respect to 


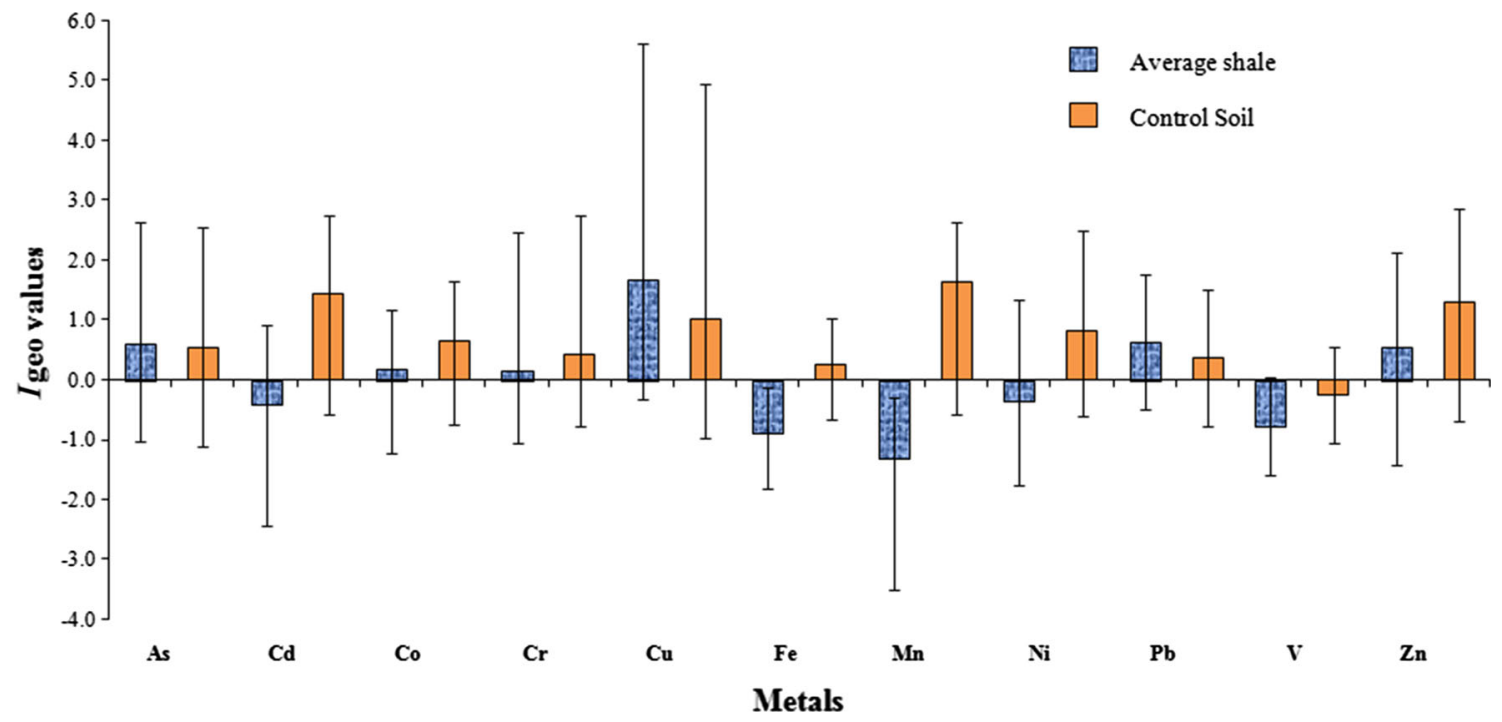

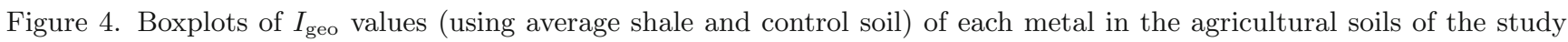
area.

Table 6. Contamination factor of metals in soil with respect to different locations of the copper mining areas of Singhbhum shear zone.

\begin{tabular}{llrlllllllllll}
\hline Code & Location & $\mathrm{As}$ & $\mathrm{Cd}$ & $\mathrm{Co}$ & $\mathrm{Cr}$ & $\mathrm{Cu}$ & $\mathrm{Fe}$ & $\mathrm{Mn}$ & $\mathrm{Ni}$ & $\mathrm{Pb}$ & $\mathrm{V}$ & $\mathrm{Zn}$ & $\mathrm{PLI}$ \\
\hline 1 & Bhatin & 1.06 & 0.28 & 0.72 & 0.83 & 1.58 & 0.45 & 0.13 & 0.52 & 1.21 & 0.70 & 0.60 & 0.61 \\
2 & Kuldiha & 1.51 & 0.48 & 1.08 & 1.42 & 1.39 & 0.82 & 0.96 & 0.67 & 2.16 & 0.71 & 0.56 & 0.97 \\
3 & Darisai & 1.74 & 1.38 & 0.64 & 1.13 & 1.86 & 0.63 & 0.55 & 0.54 & 2.28 & 0.68 & 3.05 & 1.10 \\
4 & Bodamdera & 1.38 & 0.61 & 3.36 & 8.24 & 5.14 & 0.96 & 0.91 & 4.31 & 3.42 & 0.93 & 1.52 & 2.01 \\
5 & Rakha & 0.87 & 1.05 & 0.65 & 0.99 & 2.94 & 0.54 & 0.41 & 0.62 & 1.07 & 0.50 & 1.31 & 0.85 \\
6 & Jagganathpur & 0.74 & 0.71 & 2.40 & 1.24 & 1.27 & 0.43 & 0.67 & 3.01 & 1.77 & 0.57 & 2.04 & 1.12 \\
7 & Kendadih & 9.31 & 1.28 & 2.35 & 2.58 & 12.65 & 1.33 & 0.93 & 1.54 & 2.04 & 1.32 & 2.62 & 2.35 \\
8 & Terenga & 6.92 & 2.47 & 2.08 & 8.34 & 22.12 & 1.16 & 0.94 & 2.77 & 5.13 & 1.27 & 6.54 & 3.46 \\
9 & Benasol & 2.77 & 2.41 & 1.72 & 1.85 & 5.07 & 0.97 & 0.68 & 1.12 & 4.04 & 1.24 & 4.95 & 1.99 \\
10 & Kutludih & 1.18 & 0.78 & 1.64 & 0.72 & 7.58 & 0.69 & 0.56 & 0.66 & 2.56 & 0.66 & 3.28 & 1.25 \\
11 & Ghatsila & 9.08 & 1.95 & 1.88 & 1.69 & 3.56 & 1.02 & 1.04 & 1.05 & 3.39 & 1.17 & 4.10 & 2.11 \\
12 & Chirugoda & 4.65 & 2.81 & 1.87 & 2.57 & 3.33 & 1.37 & 1.23 & 1.77 & 4.33 & 1.54 & 5.52 & 2.49 \\
13 & Sohada & 3.56 & 1.65 & 2.72 & 1.53 & 44.14 & 0.94 & 0.86 & 4.46 & 2.56 & 0.97 & 4.52 & 2.64 \\
14 & Pathergoda & 1.14 & 0.68 & 2.22 & 1.37 & 1.21 & 0.67 & 0.52 & 0.52 & 1.97 & 0.69 & 1.15 & 0.98 \\
15 & Badia & 3.93 & 2.15 & 3.02 & 0.88 & 73.65 & 0.91 & 0.51 & 4.18 & 1.77 & 1.06 & 2.34 & 2.38 \\
16 & Latia & 1.63 & 1.15 & 2.11 & 1.09 & 2.32 & 0.80 & 0.24 & 2.09 & 1.58 & 0.72 & 1.08 & 1.16 \\
\hline
\end{tabular}

the control soil. In this case also, the highest variability was observed for $\mathrm{Cu}(-0.98$ to 4.95$)$; thus indicating augmentation of the $\mathrm{Cu}$ concentrations in the study area with respect to background values also.

The degree of pollution by different metals as expressed by contamination factor $(\mathrm{CF})$, suggested that the highest contamination was for $\mathrm{Cu}$ in the soils of the study area. The contamination factors for the different metals generally followed the sequence (table 6): $\mathrm{Cu}<\mathrm{As}<\mathrm{Zn}<\mathrm{Pb}<\mathrm{Cr}<$ $\mathrm{Co}<\mathrm{Ni}<\mathrm{Cd}<\mathrm{V}<\mathrm{Fe}<\mathrm{Mn}$.
$P L I$ was calculated to evaluate the combined pollution effect by different metals at different sampling locations and is depicted in figure 5. A calculated $P L I$ value $<1$ for a location strongly advocates metal pollution (Cabrera et al. 1999). In the study area, the average $P L I$ value was calculated to be 1.72 , with minimum value of 0.61 and maximum value of 3.46 (for the location Badia). Almost 50\% of the locations of the study area fall in the category of heavy pollution with respect to $P L I$.

The $m C_{d}$ values for the different sampling locations of the study area varied from 0.73 to 8.58. The 


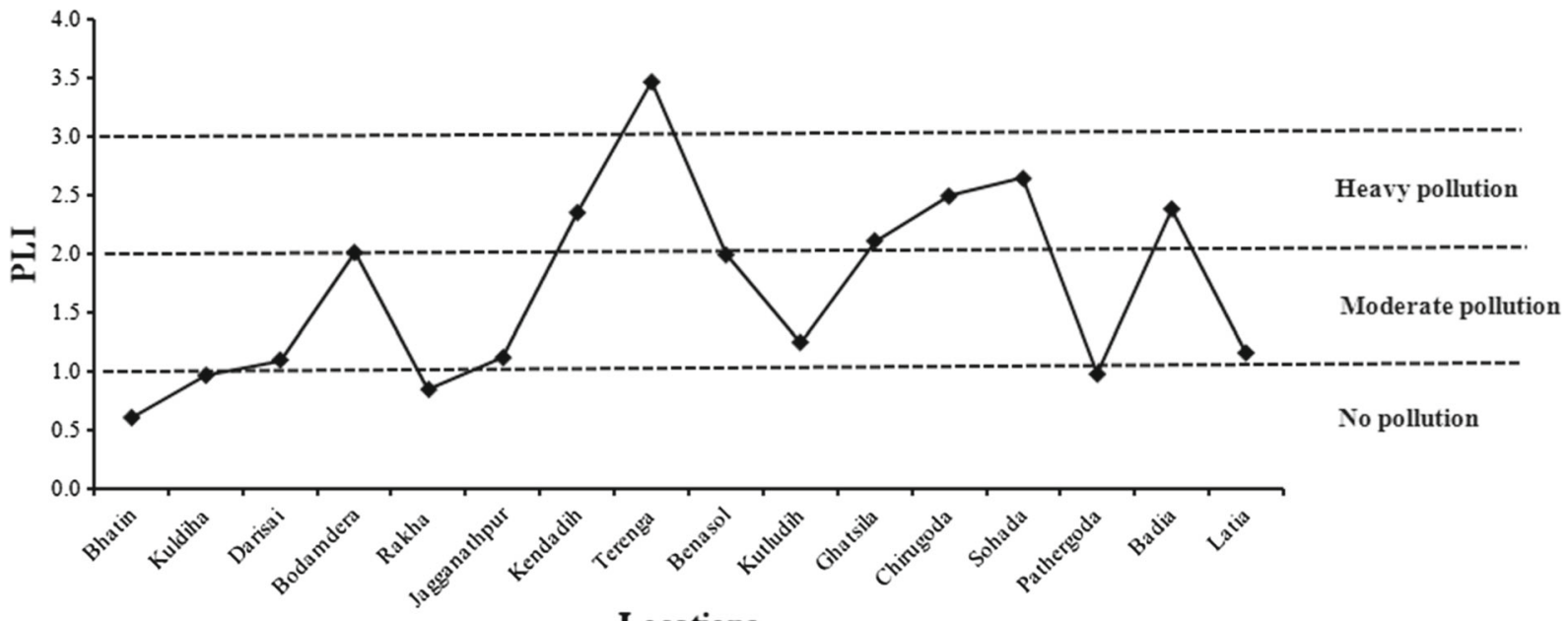

Locations

Figure 5. Pollution load index (PLI) at different locations of the study area.

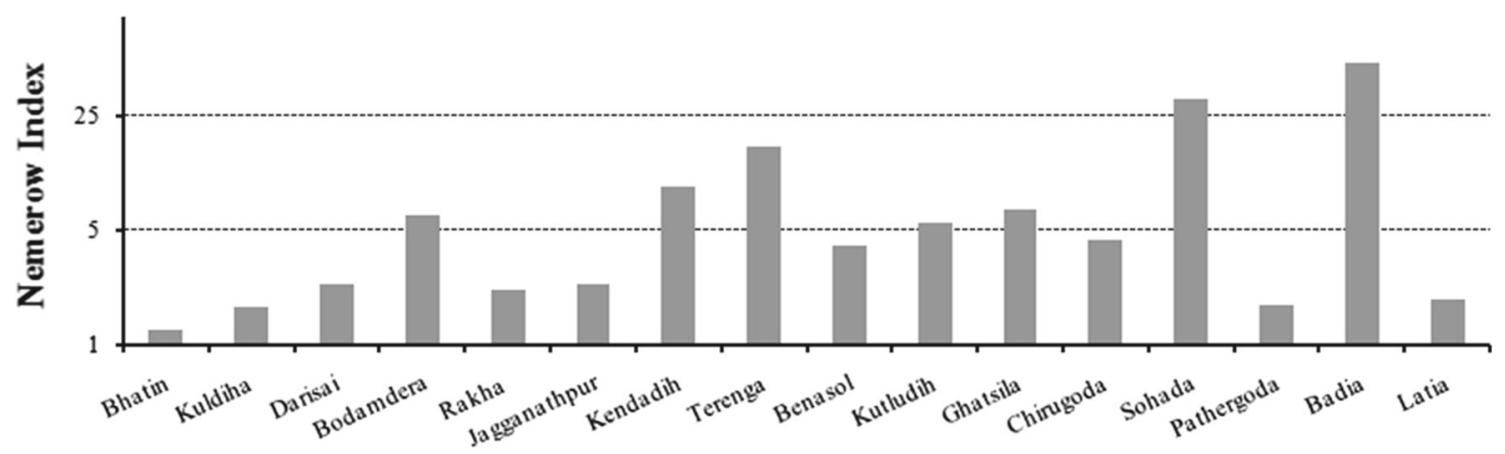

Locations

Figure 6. Nemerow index at different locations of the study area.

Table 7. Potential ecological risk indices of the agricultural soils of Singhbhum copper belt.

\begin{tabular}{|c|c|c|c|c|c|c|c|c|c|}
\hline \multirow[b]{2}{*}{ Code } & \multirow[b]{2}{*}{ Locations } & \multicolumn{7}{|c|}{$E_{r}^{i}$} & \multirow[b]{2}{*}{$R_{I}$} \\
\hline & & As & $\mathrm{Cd}$ & $\mathrm{Cr}$ & $\mathrm{Cu}$ & $\mathrm{Ni}$ & $\mathrm{Pb}$ & $\mathrm{Zn}$ & \\
\hline 2 & Kuldiha & 14.2 & 30.9 & 3.43 & 4.40 & 6.43 & 8.96 & 0.93 & 69.2 \\
\hline 3 & Darisai & 16.4 & 88.7 & 2.73 & 5.88 & 5.16 & 9.45 & 5.11 & 133.5 \\
\hline 4 & Bodamdera & 13.0 & 39.4 & 20.0 & 16.2 & 41.2 & 14.2 & 2.55 & 146.4 \\
\hline 5 & Rakha & 8.19 & 67.3 & 2.40 & 9.28 & 5.91 & 4.42 & 2.20 & 99.7 \\
\hline 6 & Jagganathpur & 6.93 & 45.4 & 2.99 & 4.01 & 28.7 & 7.34 & 3.43 & 98.9 \\
\hline 7 & Kendadih & 87.7 & 82.3 & 6.24 & 39.9 & 14.7 & 8.46 & 4.39 & 243.8 \\
\hline 8 & Terenga & 65.1 & 158.8 & 20.2 & 69.8 & 26.5 & 21.3 & 10.96 & 372.6 \\
\hline 9 & Benasol & 26.1 & 155.1 & 4.47 & 16.0 & 10.7 & 16.8 & 8.30 & 237.5 \\
\hline 10 & Kutludih & 11.1 & 50.1 & 1.75 & 23.9 & 6.35 & 10.6 & 5.49 & 109.4 \\
\hline 11 & Ghatsila & 85.6 & 125.1 & 4.08 & 11.2 & 10.0 & 14.1 & 6.87 & 257.0 \\
\hline 12 & Chirugoda & 43.8 & 180.9 & 6.23 & 10.5 & 16.9 & 18.0 & 9.24 & 285.5 \\
\hline 13 & Sohada & 33.6 & 105.9 & 3.71 & 139.3 & 42.6 & 10.6 & 7.58 & 343.2 \\
\hline 14 & Pathergoda & 10.7 & 43.7 & 3.32 & 3.81 & 4.94 & 8.17 & 1.92 & 76.6 \\
\hline 15 & Badia & 37.1 & 138.0 & 2.14 & 232.4 & 39.9 & 7.36 & 3.92 & 460.8 \\
\hline 16 & Latia & 15.4 & 73.9 & 2.64 & 7.33 & 20.0 & 6.54 & 1.80 & 127.6 \\
\hline \multicolumn{2}{|c|}{ Geometric mean } & 21.6 & 73.0 & 5.52 & 15.3 & 13.2 & 9.7 & 3.7 & 158.8 \\
\hline
\end{tabular}


locations were placed in the classes of 'unpolluted' $\left(m C_{d}<1.5\right)$ to 'highly polluted' $\left(8 \leq m C_{d} \leq\right.$ 16) as per the classification of $m C_{d}$. The average impact of all the measured metals is considered in the calculation of $m C_{d}$ and thus the contribution of one metal is diminished. As a consequence, the skewness will be meager for the $m C_{d}$ values even if the soils are highly contaminated with one of the metals. The same is depicted in the present study where the soils are highly contaminated with $\mathrm{Cu}$. But in Nemerow index, the impact of one single metal is quantified in a much more considerate way as it considers both the average and maximum contamination factors as per equation (7) (Brady et al. 2015). The Nemerow index values for the various locations of the study area ranged from 1.23 to 52.4 (figure 6) indicating seriously contaminated status $\left(P_{s} \geq 5\right)$ at nearly $50 \%$ of the locations. Thus, the findings, taking into account of $\mathrm{EF}$, $I_{\text {geo }}, \mathrm{CF}, P L I$ and Nemerow index, confirm that metal pollution in the study area is moderately to extremely serious varying between the locations and $\mathrm{Cu}$ being the most concerned metal. The highest degree of contamination was encountered at the locations near $\mathrm{Cu}$ mining and processing units.

The geometric mean $\mathrm{E}_{\mathrm{r}}^{\mathrm{i}}$ values for $\mathrm{As}, \mathrm{Cd}, \mathrm{Cr}$, $\mathrm{Cu}, \mathrm{Ni}, \mathrm{Pb}$ and $\mathrm{Zn}$ were 22.7, 80.1, 4.2, 16.5, 14.1, 10.2 and 4.1, respectively, suggesting considerable risk for $\mathrm{Cd}$. All the other metals were in the low risk category (table 7 ). The $R_{\mathrm{I}}$ ranged from 69.2 to 460.8 (geomean 172.5) representing moderate risk in the study area. Referring to the $R_{\mathrm{I}}$ category mentioned before, one sampling site was classified into very high risk and six sampling sites were classified into considerable risk. The potential ecological risks of other sites were low to moderate.

\section{Conclusions}

The levels of the metals in the agricultural soils of the copper mining areas of the Singhbhum shear zone were higher than the average shale and world average values for most of the cases. The high concentration of metals in the soils can be attributed to both natural and anthropogenic factors which are three clearly illustrated by the multivariate analysis. PCA resulted in extraction of three factors explaining $82.6 \%$ of the data variability out of which two indicated human activities and one factor indicated geogenic sources. The enrichment factor and $I_{\text {geo }}$ values indicated very high contamination with respect to $\mathrm{Cu}$ followed by $\mathrm{As}$ and $\mathrm{Zn}$ in the agricultural soils of the study area. The EF depicted least pollution with respect to $\mathrm{Mn}$ and $\mathrm{V}$. The combined pollution effect of different metals was evaluated using $P L I, R_{I}$ and Nemerow index, which revealed that $50 \%$ of the locations were in extremely polluted status with respect to metals. Only $25 \%$ of the locations could qualify to be placed in the uncontaminated category. The locations which were in close proximity to the existing or abandoned copper mining and processing units showed higher levels of metal pollution as compared to other locations and out of all the studied metals, $\mathrm{Cu}$ was the main metal of concern.

From the estimation of metal concentration in the agricultural soil samples collected from this study, we obtained a better knowledge regarding the impact of the copper mining and processing operations on the environment. Consequently, heavy metal concentrations in the soils should be periodically monitored and improved soil management practices are required to minimize possible impacts.

\section{Acknowledgements}

The authors are grateful to the Department of Science and Technology, Government of India, for providing the necessary funding for the study under the DST-Young Scientist Scheme (Grant No. YSS/2015/001211). Also authors are thankful to the Director and Environment Assessment and Remediation Section (NREM), CSIR-Central Institute of Mining and Fuel Research, Dhanbad for providing the necessary laboratory facilities and other logistic support for the study.

\section{References}

Adriano D C 2001 Trace elements in terrestrial environments; 2nd edn, Springer, Berlin.

Alloway B J 2013 Heavy metals in soils; Springer, Berlin.

Borgese L, Federici S, Zacco A, Gianoncelli A, Rizzo L, Smith D R, Donna F, Lucchini R, Depero L E and Bontempi E 2013 Metal fractionation in soils and assessment of environmental contamination in Vallecamonica, Italy; Environ. Sci. Pollut. Res. 20 5067-5075.

Bowen H J M 1979 Environmental chemistry of elements; Academic Press, New York.

Brady J, Ayoko G, Martens W and Goonetilleke A 2015 Development of a hybrid pollution index for heavy metals in marine and estuarine sediments; Environ. Monit. Assess. 187(5) 1-14. 
Bruins M R, Kapil S and Oehme F W 2000 Microbial resistance to metals in the environment; Ecotoxicol. Environ. Saf. 45(3) 198-207.

Cabrera F, Clemente L, Diaz Barrientos E, Lopez R and Murillo J M 1999 Heavy metal pollution of soils affected by the Guadiamar toxic flood; Sci. Total Environ. 242 $117-129$.

Cao H B, Chen J J, Zhang J, Zhang H, Qiao L and Men Y 2010 Heavy metals in rice and garden vegetables and their potential health risks to inhabitants in the vicinity of an industrial zone in Jiangsu, China; J. Environ. Sci. 22 $1792-1799$.

Chen H, Lu X, Li L Y, Gao T and Chang Y 2014 Metal contamination in campus dust of Xi'an, China: A study based on multivariate statistics and spatial distribution; Sci. Total Environ. 484 27-35.

Christophoridis C, Dedepsidis D and Fytianos K 2009 Occurrence and distribution of selected toxic metals in the surface sediments of Thermaikos Gulf, N. Greece. Assessment using pollution indicators; J. Hazard. Mater. 168 1082-1091.

Closs L G and Nichol I 1975 The role of factor and regression analysis in the interpretation of geochemical Reconnaissance data; Can. J. Earth Sci. 12(8) 1316-1330.

Cohen T, Hee S and Ambrose R 2001 Trace metals in fish and invertebrates of three California coastal wetlands; Mar. Pollut. Bull. 42 232-242.

Çolak M 2012 Heavy metal concentrations in sultana cultivation soils and sultana raisins from Manisa (Turkey); Environ. Earth Sci. 67 695-712.

Dunn J A and Dey A K 1942 The geology and petrology of eastern Singhbhum and surrounding areas; 69 Government of India Press.

Forstner U and Wiltman G T W 1983 Metal pollution in aquatic environment; Springer, Berlin.

Fu J, Zhao C P, Luo Y P, Liu C S, Kyzas G Z, Luo Y, Zhao D Y, An S Q and Zhu H L 2014 Heavy metals in surface sediments of the Jialu River, China: Their relations to environmental factors; J. Hazard. Mater. 270 102-109.

Gałuszka A, Migaszewski Z M, Dołȩgowska S, Michalik A and Duczmal-Czernikiewicz A 2015 Geochemical background of potentially toxic trace elements in soils of the historic copper mining area: A case study from Miedzianka Mt., Holy Cross Mountains, south-central Poland; Environ. Earth Sci. 74(6) 4589-4605.

Giri S, Singh A K and Tewary B K 2013 Source and distribution of metals in bed sediments of Subarnarekha River, India; Environ. Earth Sci. 70(7) 3381-3392.

Giri S and Singh A K 2014a Assessment of human health risk for heavy metals in fish and shrimp collected from Subarnarekha River, India; Int. J. Environ. Health Res. 24(5) 429-449.

Giri S and Singh A K 2014b Risk assessment, statistical source identification and seasonal fluctuation of dissolved metals in the Subarnarekha River, India; J. Hazard. Mater. 265 305-314.

Giri S and Singh A K 2015 Human health risk assessment via drinking water pathway due to metal contamination in the groundwater of Subarnarekha River Basin, India; Environ. Monit. Assess. 187(3) 1-14.

Giri S and Singh A K 2016 Spatial distribution of metal(loid)s in groundwater of a mining dominated area:
Recognising metal(loid)s sources and assessing carcinogenic and non-carcinogenic human health risk; Int. J. Environ. Anal. Chem. 96(14) 1313-1330.

Hakanson L 1980 An ecological risk index for aquatic pollution control. A sedimentological approach; Water Res. 14(8) 975-1001.

Hani A and Pazira E 2011 Heavy metals assessment and identification of their sources in agricultural soils of southern Tehran, Iran; Environ. Monit. Assess. 176(1-4) 677-691.

Hilton J, Davison W and Ochsenbein U 1985 A mathematical model for analysis of sediment coke data; Chem. Geol. 48 281-291.

Hu W, Huang B, He Y and Kalkhajeh Y K 2016 Assessment of potential health risk of heavy metals in soils from a rapidly developing region of China; Human Ecol. Risk Assess.: Int. J. 22(1) 211-225.

Huang G, Chen Z and Sun J 2014 Water quality assessment and hydrochemical characteristics of groundwater on the aspect of metals in an old town, Foshan, South China; $J$. Earth Syst. Sci. 123(1) 91-100.

Islam M S, Ahmed M K, Habibullah-Al-Mamun M and Raknuzzaman M 2015 Trace elements in different land use soils of Bangladesh and potential ecological risk; Environ. Monit. Assess. 187(9) 1-11.

Ji K, Kim J, Lee M, Park S, Kwon H J, Cheong H K, Jang J Y, Kim D S, Yu S, Kim Y W, Lee K Y, Yang S O, Jhung I J, YangW H, Paek D H, Hong Y C and Choi K 2013 Assessment of exposure to heavy metals and health risks among residents near abandoned metal mines in Goseong, Korea; Environ. Pollut. 178 322-328.

Kartal S, Aydin Z and Tokalioglu S 2006 Fractionation of metals in street sediment samples by using the BCR sequential extraction procedure and multivariate statistical elucidation of the data; J. Hazard. Mater. 132 80-89.

Kolsi S H, Bouri S, Hachicha W and Dhia H B 2013 Implementation and evaluation of multivariate analysis for groundwater hydrochemistry assessment in arid environments: A case study of Hajeb Elyoun-Jelma, Central Tunisia; Environ. Earth Sci. 70 2215-2224.

Kumar B, Verma V K, Naskar A K, Sharma C S and Mukherjee D P 2014 Bioavailability of metals in soil and health risk assessment for populations near an Indian chromite mine area; Human Ecol. Risk Assess.: Int. J. 20(4) 917-928.

Li W X, Zhang X X, Wu B, Sun S L, Chen Y S, Pan W Y, Zhao D Y and Cheng S P 2008 A comparative analysis of environmental quality assessment methods for heavy metal-contaminated soils; Pedosphere 18(3) 344-352.

Li Z, Ma Z, van der Kuijp T J, Yuan Z and Huang L 2014 A review of soil heavy metal pollution from mines in China: Pollution and health risk assessment; Sci. Total Environ. 468 843-853.

Liang Q, Xue Z J, Wang F, Sun Z M, Yang Z X and Liu S Q 2015 Contamination and health risks from heavy metals in cultivated soil in Zhangjiakou City of Hebei Province, China; Environ. Monit. Assess. 187(12) 1-11.

Liu X, Song Q, Tang Y, Li W, Xu J, Wu J, Wang F and Brookes P C 2013 Human health risk assessment of heavy metals in soil-vegetable system: A multi-medium analysis; Sci. Total Environ. 463 530-540. 
Loska K, Wiechula D and Korus I 2004 Metal contamination of farming soils affected by industry; Environ. Int. 30 159-165.

Ma L, Sun J, Yang Z and Wang L 2015 Heavy metal contamination of agricultural soils affected by mining activities around the Ganxi River in Chenzhou, southern China; Environ. Monit. Assess. 187731.

Mileusnić M, Mapani B S, Kamona A F, Ružičić S, Mapaure I and Chimwamurombe P M 2014 Assessment of agricultural soil contamination by potentially toxic metals dispersed from improperly disposed tailings, Kombat mine, Namibia; J. Geochem. Explor. 144 409-420.

Miller N J and Miller J C 2000 Statistics and chemometrics for analytical chemistry; 4th edn, NJ7, Pearson Education, Englewood Cliffs.

Mirzaei R, Teymourzade S, Sakizadeh M and Ghorbani H 2015 Comparative study of heavy metals concentration in topsoil of urban green space and agricultural land uses; Environ. Monit. Assess. 187(12) 1-12.

Mukherjee B 1968 Genetic significance of trace elements in certain rocks of Singhbhum, India; Min. Mag. 36(281) $661-670$

Muller G 1969 Index of geoaccumulation in sediments of the Rhine River; J. Geog. 2 108-118.

Muller G 1979 Schwermetalle in den Sedimenten des RheinsVeranderungen seit 1971; Umschau 79 778-783.

Preston M R and Chester R 1996 Chemistry and pollution of the marine environment; In: Pollution: causes, effects and control (ed.) Harison R M, 3rd edn, Royal Soc. Chem. UK, pp. 26-51.

Prüss-Ustün A, Vickers C, Haefliger P and Bertollini R 2011 Knowns and unknowns on burden of disease due to chemicals: A systematic review; Environ. Health. 10(1) 1.

Rubio R and Ure A M 1993 Approaches to sampling and sample pretreatments for metal speciation in soils and sediments; Int. J. Environ. Anal. Chem. 51 205217.

Sakram G, Machender G, Dhakate R, Saxena P R and Prasad M D 2015 Assessment of trace elements in soils around Zaheerabad Town, Medak District, Andhra Pradesh, India; Environ. Earth Sci. 73(8) 45114524.

Salomons W and Forstner U 1984 Metals in the hydrocycle; Springer, Berlin, pp. 63-98.
Schiff K C and Weisberg S B 1999 Iron as a reference element for determining trace metal enrichment in southern California coastal shelf sediments; Mar. Environ. Res. 48 161-176.

Skordas K, Papastergios G and Filippidis A 2013 Major and trace element contents in apples from a cultivated area of Central Greece; Environ. Monit. Assess. 185 8465-8471.

Sutherland R A 2000 Bed sediment-associated trace metals in an urban stream, Oahu, Hawaii; Environ. Geol. 39 611-627.

Tomlison L, Wilson L G, Harris R and Jeffrey D W 1980 Problems in the assessments of heavy metal levels in estuaries and formation of pollution index; Helgolander Meeresuntersuchungen 33 566-575.

Turekian K K and Wedepohl K H 1961 Distribution of the elements in some major units of the earth's crust; $A m$. Geol. Soc. Bull. 72 175-182.

Turner A and Millward G E 2000 Particle dynamics and trace metal reactivity in estuarine plumes; Estuar. Coast. Shelf Sci. 50 761-774.

Upadhyay A K, Gupta K K, Sircar J K, Deb M K and Mundhara G L 2006 Heavy metals in freshly deposited sediments of the river Subarnarekha, India: An example of lithogenic and anthropogenic effects; Environ. Geol. 50(3) 397-403.

USEPA (United States Environmental Protection Agency) 1996 EPA method 3052: Microwave assisted acid digestion of siliceous and organically based matrices; US Environmental Protection Agency, Office of Solid Waste and Emergency Response, Government Printing Office, Washington.

Wang Y, Yang Z, Shen Z, Tang Z, Niu J and Gao F 2011 Assessment of heavy metals in sediments from a typical catchment of the Yangtze River, China; Environ. Monit. Assess. 172 407-417.

Wu Q, Leung J Y S, Geng X, Chen S, Huang X, Li H, Huang Z, Zhu L, Chen J and Lu Y 2015 Heavy metal contamination of soil and water in the vicinity of an abandoned e-waste recycling site: Implications for dissemination of heavy metals; Sci. Total Environ. 506-507 217-225.

Xu Z, Li J, Pan Y and Chai X 2016 Human health risk assessment of heavy metals in a replaced urban industrial area of Qingdao, China; Environ. Monit. Assess. 188(4) $1-12$. 